\title{
Comparison of impact of immersed and micro-jet cooling during quenching on microstructure and mechanical properties of hypoeutectic silumin AISi7Mg0.3
}

\author{
Porównanie wpływu chłodzenia zanurzeniowego \\ oraz mikrostrumieniowego przy przesycaniu \\ na mikrostrukturę i właściwości mechaniczne \\ odlewniczego siluminu podeutektycznego typu AlSi7Mg0.3
}

\begin{abstract}
This article presents research the results of the mechanical properties at the ambient temperature of hypoeutectic cast silumin EN AC-AISi7Mg0.3 (according to EN 1706:2011; analogic to alloy A356 according to AA - the Aluminum Association). As related to the commonly known and used process of immersion during quenching, the research also used a micro-jet system of cooling. After quenching, the experimental samples were also submitted to artificial aging in three different variations. The achieved results were compared with the mechanical properties of the alloy in the as-cast state.

Samples from the experimental alloy were subjected to micro-jet cooling during quenching; in principle, they had a similar level of properties as related to the samples that were cooled by immersion; only in some cases did the micro-jet cooling give better results. Further works in the field should be aimed at constructing machines for micro-jet cooling with water pressure levels significantly higher than the typical pressure of community waterworks.
\end{abstract}

Keywords: cast aluminum alloys, heat treatment, quenching, immersion cooling, micro-jet cooling, artificial aging, mechanical properties, metallographic research

\section{Streszczenie}

W artykule zostały zaprezentowane wyniki badań podstawowych właściwości mechanicznych (UTS, YS, E, N, HB) w temperaturze pokojowej podeutektycznego siluminu odlewniczego EN AC-42100 (EN AC-AlSi7Mg0.3) (zgodnie z EN 1706:2011; analogia stopu A356 według Aluminium Association). W odniesieniu do powszechnie znanego i stosowanego zabiegu chłodzenia

Edward Czekaj Professor: Foundry Research Institute, Krakow, Poland; Zofia Kwak M.Sc. Eng., Aldona Garbacz-Klempka Ph.D. Eng.: AGH University of Science and Technology, Faculty of Foundry Engineering, Krakow, Poland; edward.czekaj@iod.krakow.pl 
zanurzeniowego ( $($, ang. immersing) podczas przesycania, w badaniach wykorzystywano również mikrostrumieniowy ( $M$, ang. micro-jet) system chłodzenia. Po przesycaniu - metodą chłodzenia zanurzeniowego lub mikrostrumieniowego - próbki doświadczalne poddawane były także sztucznemu starzeniu w trzech różnych wariantach: S1, S2 i S3. Uzyskiwane wyniki były porównywane z właściwościami mechanicznymi stopu w stanie po odlaniu (stan $F$, ang. fabrication). Próbki z doświadczalnego stopu poddane mikrostrumieniowemu chłodzeniu przy przesycaniu miały w zasadzie podobne właściwości mechaniczne w stosunku do właściwości próbek chłodzonych zanurzeniowo i tylko w niektórych przypadkach mikrostrumieniowe chłodzenie dawało lepsze wyniki. Dalsze prace w tym obszarze powinny dotyczyć konstruowania urządzeń do mikrostrumieniowego chłodzenia o ciśnieniach wody znacznie przewyższających ciśnienie sieci wodociągowej, tj. do poziomu nawet kilkuset barów.

Słowa kluczowe: stopy aluminium, obróbka cieplna, przesycanie, chłodzenie zanurzeniowe, mikrostrumieniowe chłodzenie, sztuczne starzenie, właściwości mechaniczne, badania metalograficzne

\section{Introduction}

Heat treatment in the manufacturing processes of cast construction elements is a very important technological operation that impacts the physico-chemical and/or mechanical properties (which ultimately determine the exploitation features). The aims of heat treatment are to reduce internal stresses and achieve dimensional stability. These desired features are a consequence of changes in the microstructure of alloys under heat impact for a specific time [1].

In general, heat treatment can be divided into three stages:

1) solution treatment, which leads the saturation of the solid solution by alloying elements to the formation of alloying additions and/or intermetallic phases in the matrix;

2) quenching, which keeps the alloying element content over the solubility limit; i.e., withholding alloying additions in the solid solution (aluminum);

3) aging; i.e., the processes of decomposition of a super saturated solid solution resulting in the formation of fine scale precipitate development in the boundaries of the solid solution $\alpha_{\text {Al }}$ of the reinforcing (intermetallic) precipitation phases [2].

For alloys produced from aluminum alloys in the European Union and United States, five basic states are applied (whose characteristics are presented in Table 1).

Burning-in during the dissolving (homogenization) of the alloys with an aluminum matrix is most often conducted at a temperature of $430-545^{\circ} \mathrm{C}$ depending on the chemical composition, design, and weight of the castings. The time of burning-in the alloy during dissolution (homogenization) is from 2 hours to 24 hours depending on the average thickness of the casing's wall $[2,4-6]$. 
Table 1. Indication of basic states of castings produced from aluminum alloys and their brief characteristics [2-5]

\begin{tabular}{|c|c|c|c|c|}
\hline No. & State identification & Dissolution & Quenching & Aging \\
\hline 1. & F & no & no & no $^{1)}$ \\
\hline 2. & T4 & yes & yes & ${\text { no } / \text { yes }^{2)}}^{2}$ \\
\hline 3. & T5 & no & no & yes $^{3)}$ \\
\hline 4. & T6 & yes & yes & yes $^{4)}$ \\
\hline 5. & T7 & yes & yes & yes $^{5)}$ \\
\hline
\end{tabular}

1) natural aging can take place after potential quenching in the manufacturing process (casting), as, for example, in the alloys of the system Al-Zn-Mg-Cu

2) purposeful natural aging at the ambient temperature for a specific time

3) artificial aging at a higher temperature

4) in order to improve tensile strength (mainly $Y S$ ) at the expense of plasticity

5) artificial aging at a temperature higher than the one for the T6 state in order to achieve dimensional stabilization at the expense of lowered tensile properties

The aim of quenching is to retain the alloying additions in the solid solution. To this end, the alloy should be quickly cooled from the solutionizing temperature (homogenization) to a possibly low temperature, however at such a level and speed that do not cause distortion in the castings.

Quick cooling during quenching allows us to achieve the best set of strength and plasticity properties in the entire cycle of heat treatment. In a general form, it can be expressed by the Quality Index (for example), which characterizes the ability of the material (aluminum alloy) to counteract static and dynamic loads under exploitation $[7,8]$.

At the Foundry Research Institute in Krakow (Poland), a prototype machine [9] was built for micro-jet cooling (further indicated as $-M$ ) of samples during quenching. The stand (together with a furnace for homogenization and a control-measuring apparatus) is shown (see Fig. 1 in Section 2.1) in the following part of the present publication which regards the research methodology.

The mechanical properties of cast aluminum alloys, including the hypoeutectic silumin Al-Si-Mg, strongly depend on the parameters (temperature and time) of artificial aging. However, a significant impact on the processes of precipitation hardening during quenching has the quality of quenching and its main factor - the rate of cooling [10].

The aim of the present work is to compare the impact of the method of cooling during quenching - by immersion ( $I$ ) or micro-jetting $(M)$ - on the basic mechanical properties at the ambient temperature; additionally, the influence of cooling was analyzed for three variations of artificial aging: $S 1, S 2, S 3$, in a changeable system temperature-time. 


\section{Material and methods}

\subsection{Stand for micro-jet treatment}

The dimensions of a prototype machine for micro-jet cooling during quenching are presented in Figure 1. The apparatus also consists of a high-temperature furnace for heating samples (see Fig. 1b), a digital recorder for temperature changes with a control computer (see Fig. 1a), and an additional connection supplying the micro-jet module with the cooling medium (see Fig. 1c). The main module of the micro-jet stand was manufactured by Swiss company Novalrec Sarl - Vértoz. The micro-jet consists of a high number of micro-nozzles (approx. 1100) with a diameter of approx. $100 \mu \mathrm{m}$, from which the cooling medium flows out at a high speed.
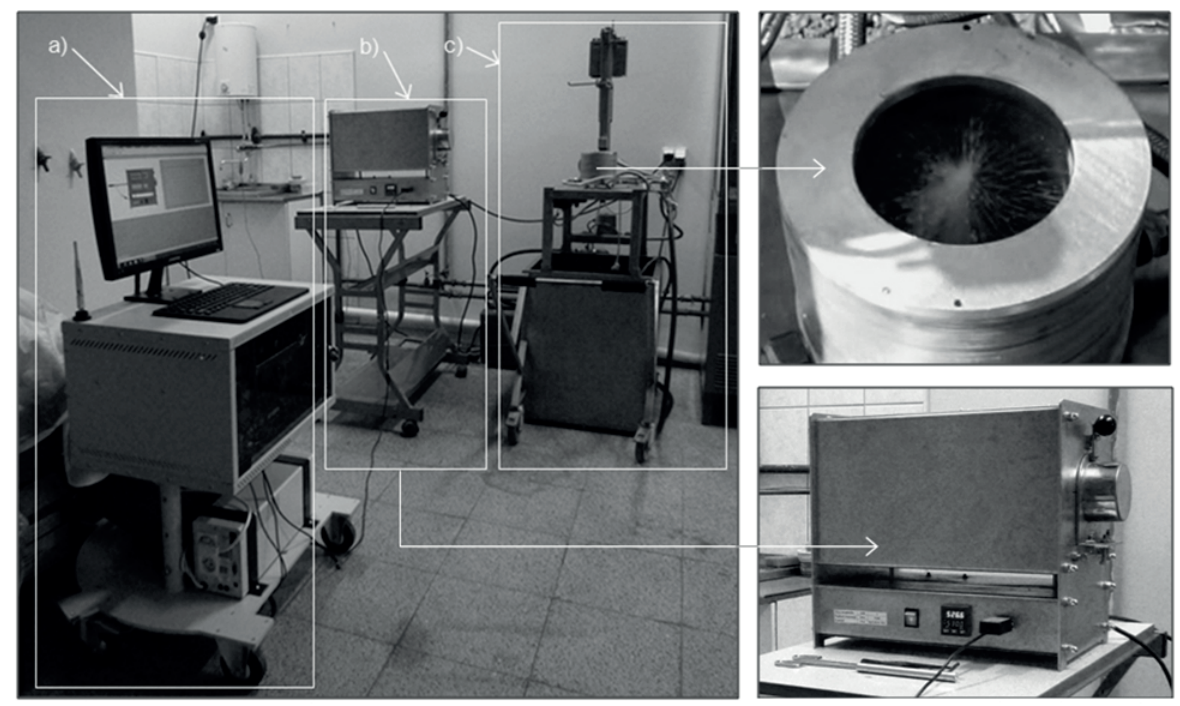

Fig. 1. General view of stand for micro-jet treatment: a) digital recorder for temperature changes together with control module; b) furnace for heating and holding samples at required temperature before quenching; c) apparatus for cooling with micro-jet module

The samples before immersion and micro-jet quenching were held at a temperature of $530^{\circ} \mathrm{C}$ for two hours. During micro-jet cooling, water from the waterworks was used with a pressure of approx. 5 bar. Three variations of artificial aging were used. The parameters were selected on the basis of the literature and experience of the authors:

$\mathrm{S} 1-$ at $155^{\circ} \mathrm{C}$ for $10 \mathrm{~h}$,

$\mathrm{S} 2$ - at $175^{\circ} \mathrm{C}$ for $8 \mathrm{~h}$,

$\mathrm{S3}-$ at $205^{\circ} \mathrm{C}$ for $6 \mathrm{~h}$. 


\subsection{Research material}

Experimental castings of the aluminum alloys were made in the laboratory hall of the Department of Non-ferrous Metal Alloys of the Foundry Research Institute in Krakow. The crucible was chamotte-graphite with a volume of approx. $100 \mathrm{~kg}$ of the Al alloy.

After loading the furnace, the metallic charge was pre-heated and then melted and over-heated above the melting temperature (by approx. $100^{\circ} \mathrm{C}$ ). The temperature of the liquid metal was measured with the use of a thermo-element 2xNiCr-Ni type K-2 with an accuracy of $\pm 5^{\circ} \mathrm{C}$.

Bars for tensile test (see Fig. 2) were cast in a metal mold (a die - see Fig. 3), which from the inside were cladded with Kokilokryt on the basis of colloidal graphite and heated before pouring to a temperature within a range of $220-250^{\circ} \mathrm{C}$.

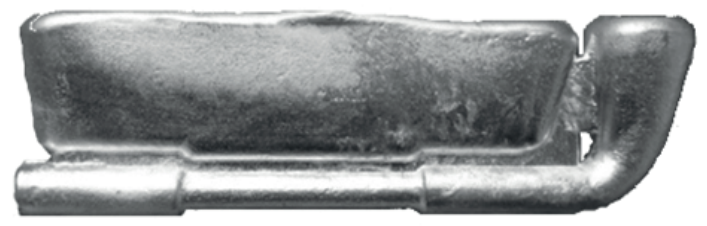

Fig. 2. Round sample for tensile tests with gating system and riser

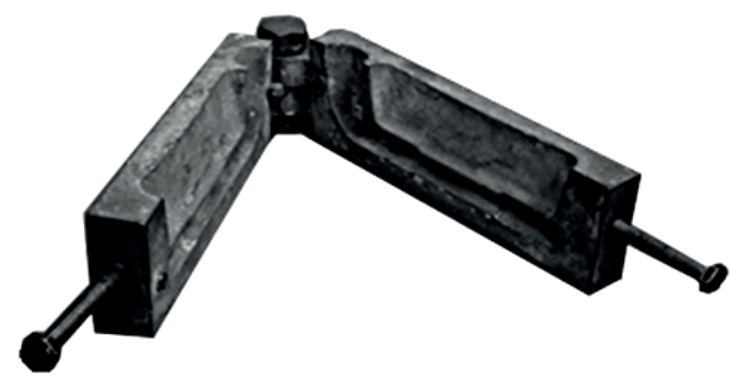

Fig. 3. Metal (cast iron) mold for casting bars for strength test

\subsection{Chemical composition of alloy}

The object of the research was alloy EN AC-AlSi7Mg0.3 [3], analogic to American alloy A356 $[4,5]$. The temperature of metal in the crucible before pouring was within a range of $720-740^{\circ} \mathrm{C}$.

The chemical composition of the aluminum alloys used in the research (cast silumins) is presented in Table 2. 


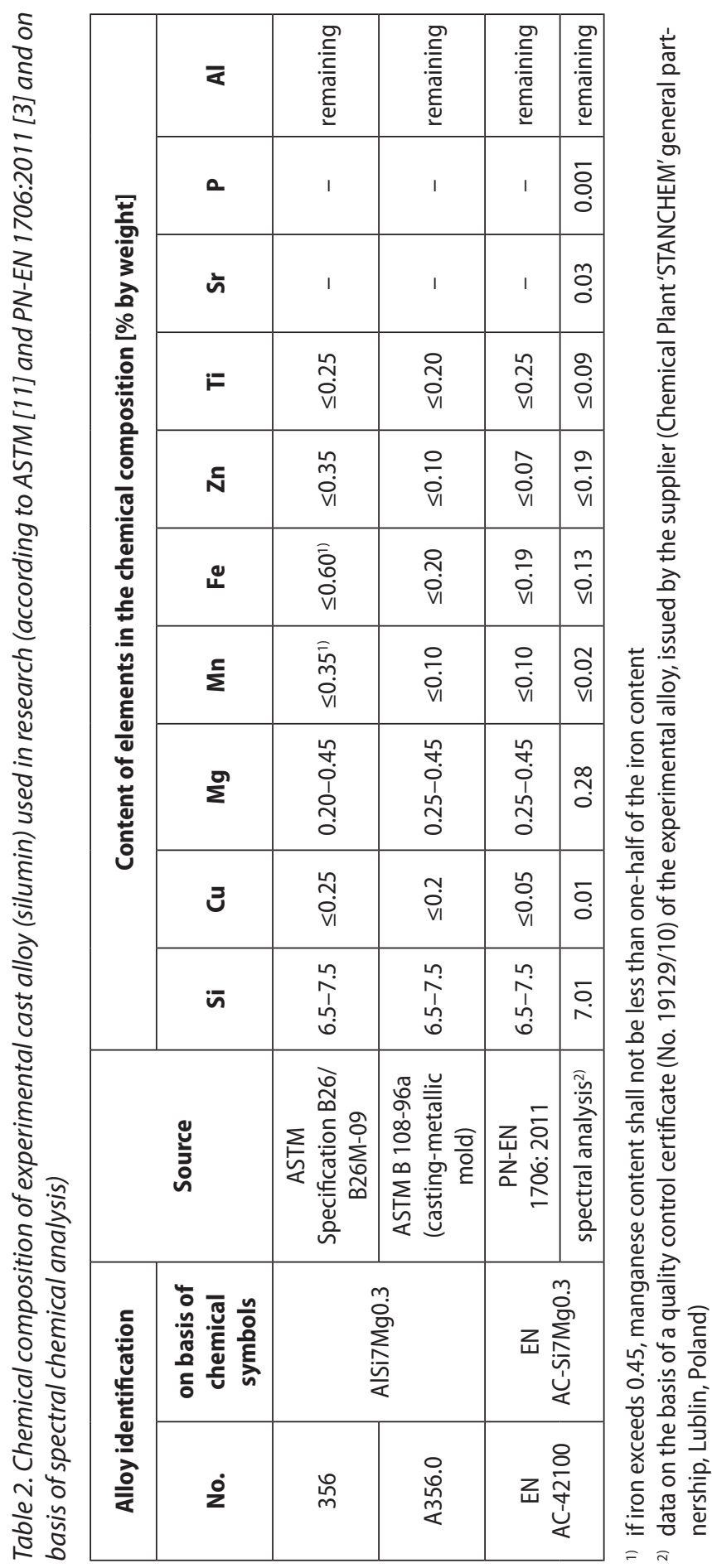




\subsection{Applied apparatus}

The analysis of the microstructure was conducted with metallographic microscope Zeiss Axio Observer Z1m. Observations and photographs of the microstructure were made in a bright visual field. In order to reveal the microstructure, the metallographic specimens were etched in a reagent Mi1Al according to PN-75/H-04512.

The study of mechanical properties (UTS, YS) was performed at room temperature $\left(\sim 20^{\circ} \mathrm{C}\right)$ using an EU-20 tensile testing machine. The hardness was measured with the Brinell hardness test method on universal hardness tester Zwick/Roell ZHU 250 (also at a temperature of $\sim 20^{\circ} \mathrm{C}$ ).

\subsection{DSC analysis and cooling curves}

In order to determine the proper parameters for conducting thermal treatment, a DSC analysis was made. The research results of heating and cooling the experimental alloy AlSi7Mg0.3 $+\mathrm{Ti}+\mathrm{Sr}$ poured to a casting die (see Fig. 4 ) are the basis for the temperature of quenching.

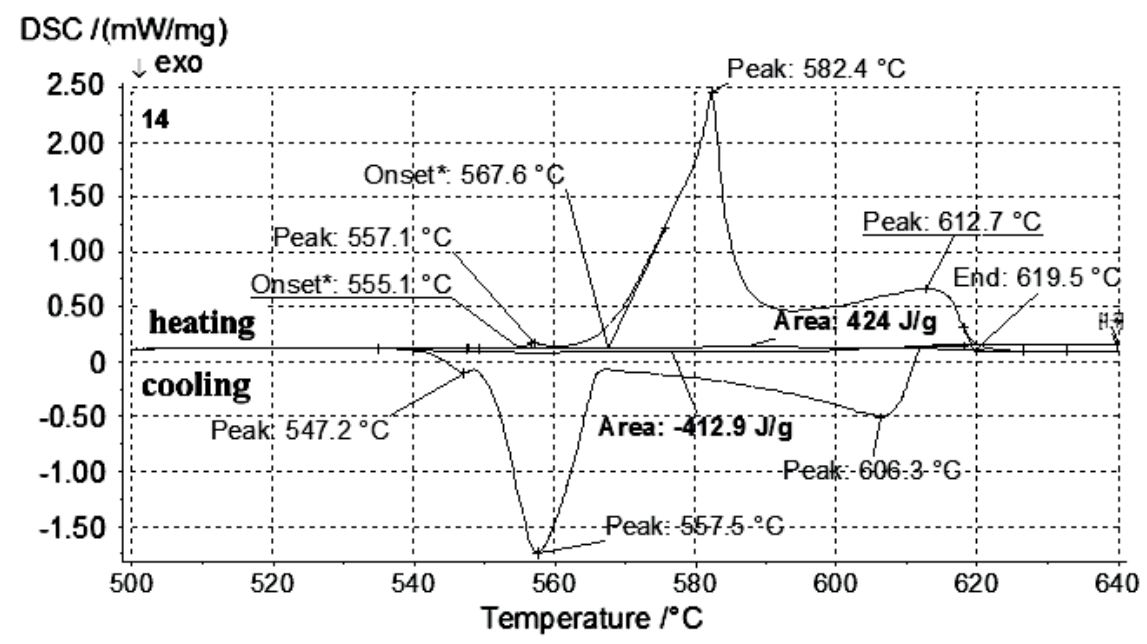

Fig. 4. Heating and cooling runs of experimental alloy AISi7MgO $3+3 i+\mathrm{Sr}$

After the analysis of temperatures corresponding to the peaks recorded on the DSC curves of the experimental alloy, a decision was made to hold the sample before quenching at $530^{\circ} \mathrm{C}$.

The diagrams in Figures $5 \mathrm{a}$ and $5 \mathrm{~b}$ show typical cooling and heating curves for instantaneous values of their speed depending on the applied method for alloy AlSi7Mg0.3 + $+\mathrm{Ti}+\mathrm{Sr}$. 
a)

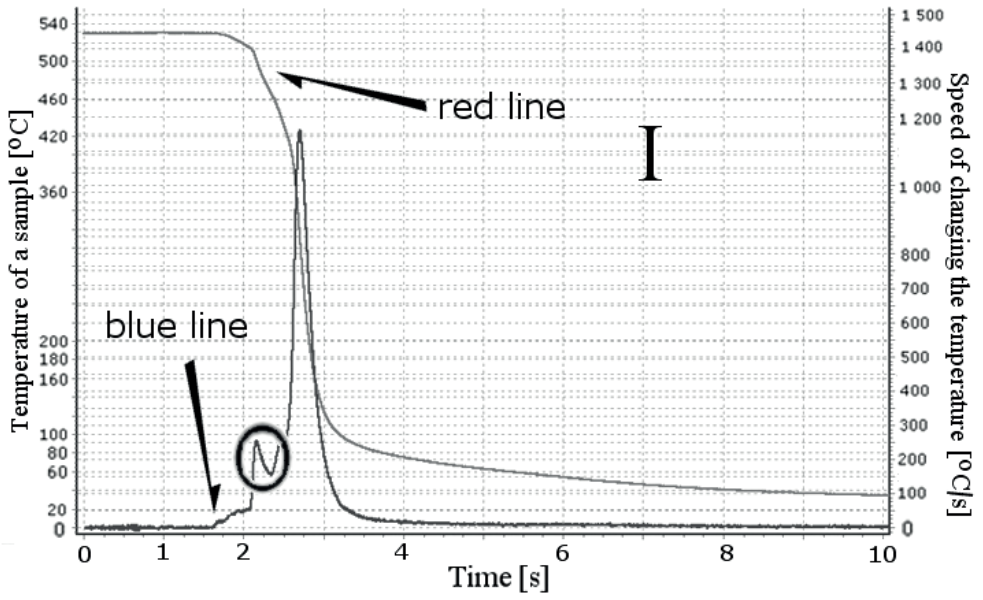

b)

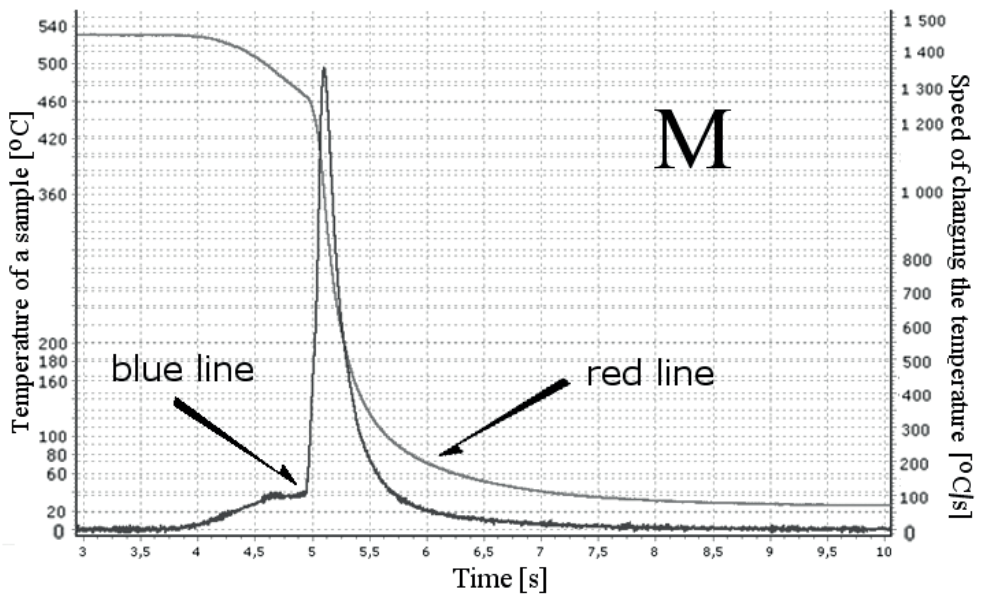

Fig. 5. Cooling curves (red lines) and instantaneous values of their speed (blue lines) (in water) of experimental samples made of alloy AISi7Mg0.3: a) immersion - l; b) micro-jet - $M$

It is worth noticing (Fig. 5b) that, in the case of micro-jet cooling after just over $10 \mathrm{~s}$, the sample reached the temperature of the cooling medium (i.e., water, $\sim 20^{\circ} \mathrm{C}$ ), whereas the temperature decreases slowly in the immersion variation (Fig. 5a), and it is within the range of $40^{\circ} \mathrm{C}$ for a longer time. In the case of immersion cooling the samples after approx. $2 \mathrm{~s}$, we can observe a peak (Fig. $5 \mathrm{a}$, green circle) that is likely related to the evaporation of water and the formation of an air layer near the surface of the sample, which momentarily decreases the rate of cooling. 


\section{Research results and discussion}

\subsection{Analysis of metallographic examination}

The results of the microscopic observations of alloy EN AC-AISi7Mg0.3 in states $F, I$, and $M$ are presented in Figures 6-8.

a)

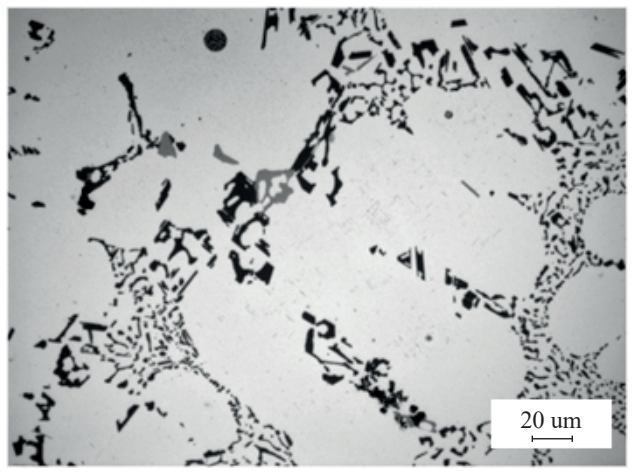

b)

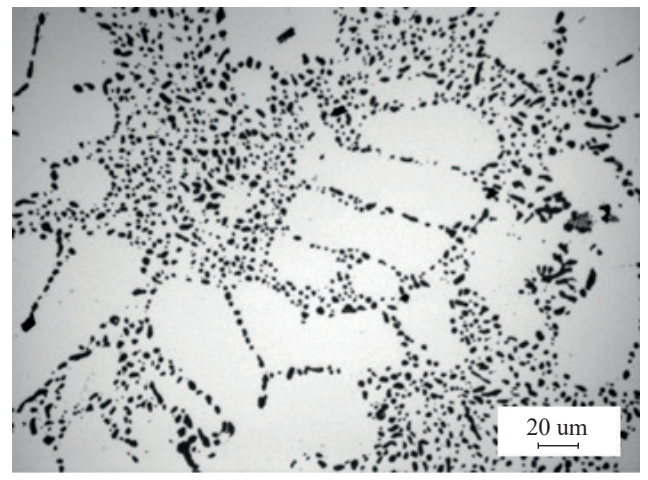

Fig. 6. Microstructure of experimental hypoeutectic silumin in following states: a) F - as-cast; b) $F+M$ - as-cast and micro-jet quenching

a)

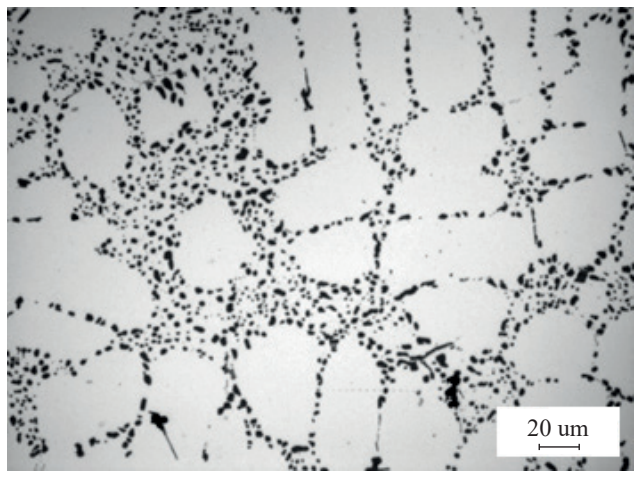

b)

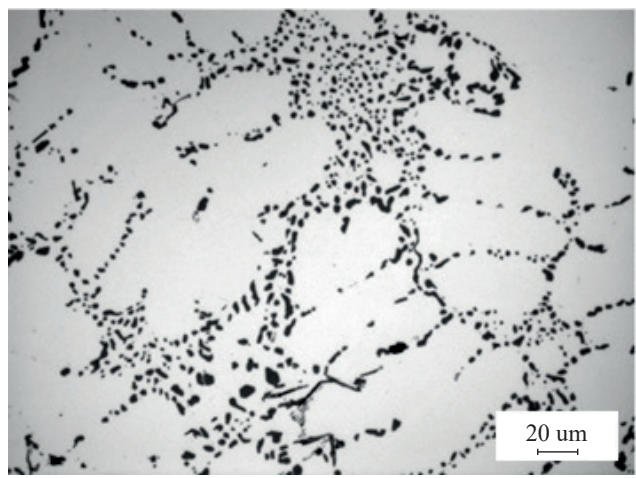

Fig. 7. Microstructure of experimental hypoeutectic silumin in following states: a) $F+I+S 2-$ as-cast $F$, immersion quenching I and artificial aging $S 2\left(175^{\circ} \mathrm{C}, 8 \mathrm{~h}\right)$; b) $F+M+S 2$ - as-cast $F$, micro-jet quenching $M$, and artificial aging $S 2\left(175^{\circ} \mathrm{C}, 8 \mathrm{~h}\right)$ 
a)

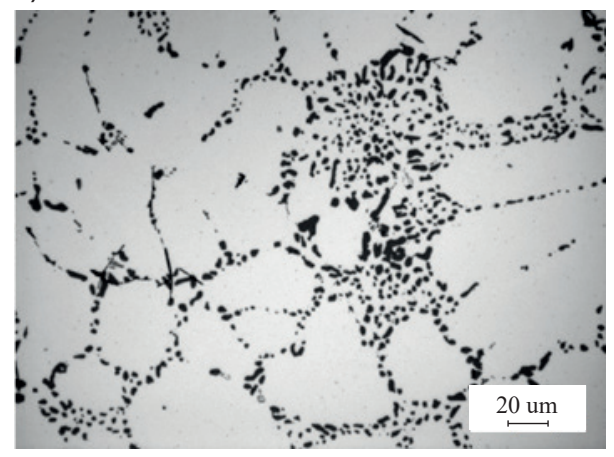

b)

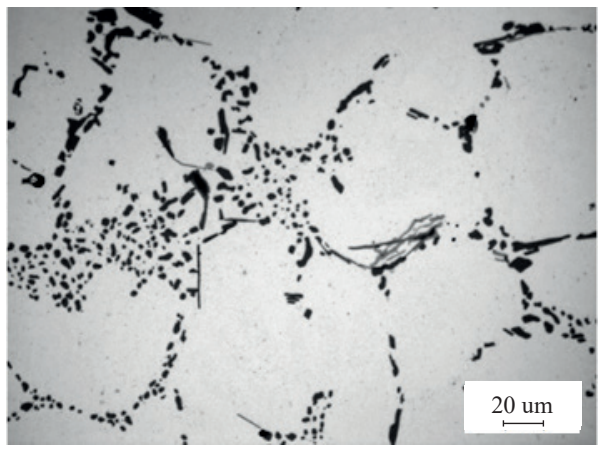

Fig. 8. Microstructure of silumin in following states: a) $F+M+S 1$ - as-cast $F$, micro-jet quenching $M$, and artificial aging $\left.S 1\left(155^{\circ} \mathrm{C}, 10 \mathrm{~h}\right) ; b\right) F+M+S 3$-as-cast $F$, micro-jet quenching $M$, and artificial aging $\mathrm{S} 3\left(205^{\circ} \mathrm{C}, 6 \mathrm{~h}\right)$

The microstructure of the experimental hypoeutectic silumin Al-Si-Mg with micro-additions of grain refiner (Ti) and modifier ( $\mathrm{Sr}$ ) (Fig. 6a) in as-cast state $F$ consists of fragmented dendrites $\alpha_{A I^{-}}$of the solid solution, modified silica eutectics $\left(\alpha_{A I}+\beta_{\mathrm{Si}}\right)$, and precipitations at the boundaries of the grains of the $\beta\left(\mathrm{Mg}_{2} \mathrm{Si}\right)$ phase in the form of 'Chinese writing.'In the microphotographs from the light microscope, we can also observe (though rarely) needlelike precipitations of the iron phase $\beta-\mathrm{Al}_{5} \mathrm{FeSi}$; moreover, we can observe a small amount of porosity caused by gas shrinkage. Holding the samples for $2 \mathrm{~h}$ at $530^{\circ} \mathrm{C}$ before quenching causes spheroidization of the eutectic silica (Fig. 6b). This spheroidization is embedded in the further stages of heat treatment - during artificial aging types $S 1, S 2$, and $S 3$ (Figs. 7, 8). For states $F+I+S 2$ and $F+M+S 2$ (Fig. 7), the rounding of the eutectic silica is very evident, which has its consequences in the mechanical properties (high strength and plasticity) (see Figs. 9, 10 in next Section). The microstructures of hypoeutectic silumin EN AC-AISi7Mg0.3 are very similar in principle in the states after quenching $(I$ and $M)$ and with additional aging $(S 1, S 2$, and $S 3)$. However, in the samples that underwent aging $(S 1, S 2$, and $S 3)$ and after quenching (types $/$ and $M$ ), we can see fine-sized precipitations of the intermetallic reinforcing phases in areas $\alpha_{A \mid}$ - of the solid solution (though they are hardly visible). They are most-evident and relatively large in the case of aging $S 3\left(205^{\circ} \mathrm{C} ; 6 \mathrm{~h}\right)$ (Fig. $\left.8 \mathrm{~b}\right)$. In order to explain the differences in the examined mechanical properties, a further metallographic analysis with the use of a scanning microscope would be helpful.

\subsection{Results of mechanical tests}

\section{Strength parameters (UST, YS)}

In Figure 9, the examination results of the ultimate tensile strength of the examined alloy are presented in the following states: as-cast $(F)$, after immersion quenching in water $(I)$, and micro-jet quenching with water $(M)$ and artificial aging ( $S 1, S 2$, and $S 3)$. 


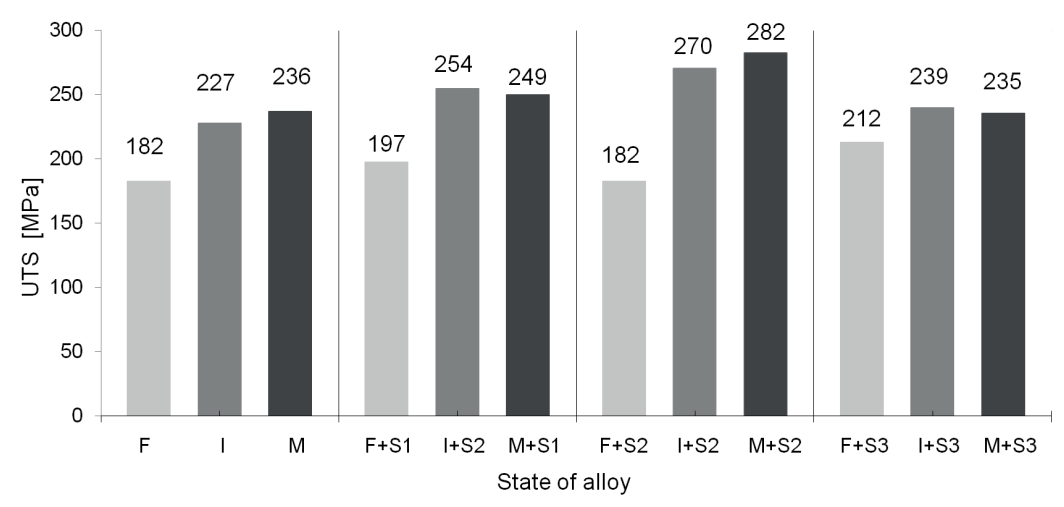

Fig. 9. Changes in ultimate tensile strength UTS (at ambient temperature) for AlSi7Mg0.3 in as-cast state (F) or depending on method of cooling after quenching (I or M), and type of aging (S1, S2, or S3)

According to PN-EN 1706:2011, state $F+S 1$ corresponds to state type T5; i.e., controlled cooling during casting and artificial aging. Whereas states I and $M+$ artificial aging $(S 1, S 2$, and $S 3)$ - are indeed thermal treatment type T6. The highest tensile strength properties (Fig. 9) were achieved in the case of applying artificial aging type $S 2$ - a temperature of $175^{\circ} \mathrm{C}$ and time of $8 \mathrm{~h}$ holding the samples at this temperature. Slightly worse parameters (yet still at a high level) correspond to artificial aging $51\left(155^{\circ} \mathrm{C}, 10 \mathrm{~h}\right)$. The lowest UTS parameters were recorded for variation $S 3\left(205^{\circ} \mathrm{C}, 6 \mathrm{~h}\right)$.

Figure 10 presents the examination results of yield stress (YS) as-cast (F) after immersion quenching $(I)$ or micro-jet quenching $(M)$ and artificial aging $(S 1, S 2, S 3)$.

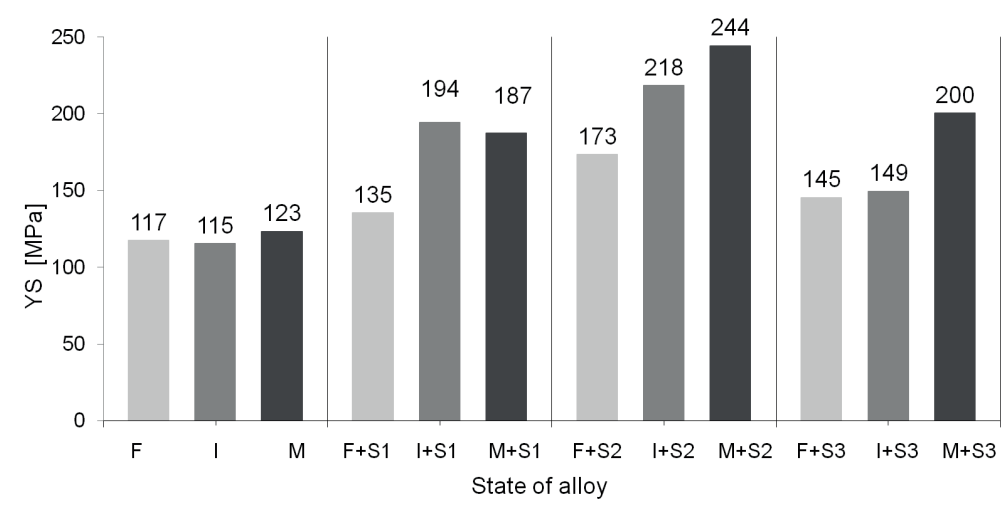

Fig. 10. Changes in yield stress YS (at ambient temperature) of hypoeutectic silumin EN AC-42100 (EN AC-AlSi7Mg0.3) in as-cast state (F) or depending on method of cooling during quenching (I or M) and type of aging (S1, S2, or S3) 
The highest $Y S$ parameters were achieved in the case of applying artificial aging type $S 2\left(175^{\circ} \mathrm{C}, 8 \mathrm{~h}\right)$ (Fig. 10). Slightly worse parameters (yet still at a high level) correspond to artificial aging type $S 3\left(205^{\circ} \mathrm{C}, 6 \mathrm{~h}\right)$ while applying micro-jet cooling. The lowest $Y S$ parameters were recorded for the variation with the lowest temperature and the shortest time of aging.

Micro-jet cooling was most-beneficial for states $M$ and $M+S 2$ from the perspective of yield tensile strength; in the case of yield stress, cooling was additionally beneficial after the heat treatment process for type $M+S 3$.

\section{Brinell hardness tests}

Figure 11 presents the results of hardness examinations determined with the Brinell hardness test method $(H B)$ as-cast $(F)$, after quenching and artificial aging.

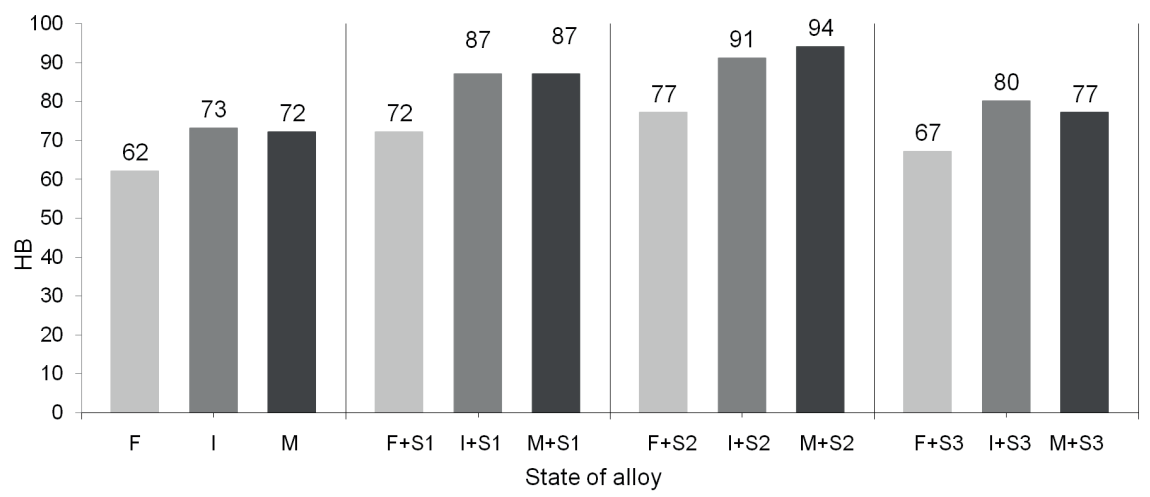

Fig. 11. Changes in hardness HB of silumin AlSi7Mg0.3 in state (F) and depending on method of cooling during quenching (I or $M$ ) and type of aging (S1, S2, or S3)

During the analysis of hardness measured with the Brinell method (Fig. 11), the highest hardness $(94 \mathrm{HB})$ can be observed for micro-jet quenching $(M)$ together with aging $S 2\left(175^{\circ} \mathrm{C}, 8 \mathrm{~h}\right)$. Hardness at this level was achieved by samples in states $I+S 1$ and $M+S 1$. In other cases, immersion cooling was more beneficial . During the casting of silumin AlSi7Mg0.3 in dies, there occurs a certain level of over-quenching of the $\alpha_{A^{-}}$solid solution; with optimal aging, its hardness can be increased (similar to its tensile strength properties).

\section{Results of elongation tests $(E)$}

Figure 12 presents elongation test results in the following states: as-cast $(F)$, immersion $(I)$ or micro-jet $(M)$ cooling (quenching), and artificial aging (S1, $S 2$, and $S 3$ ). 


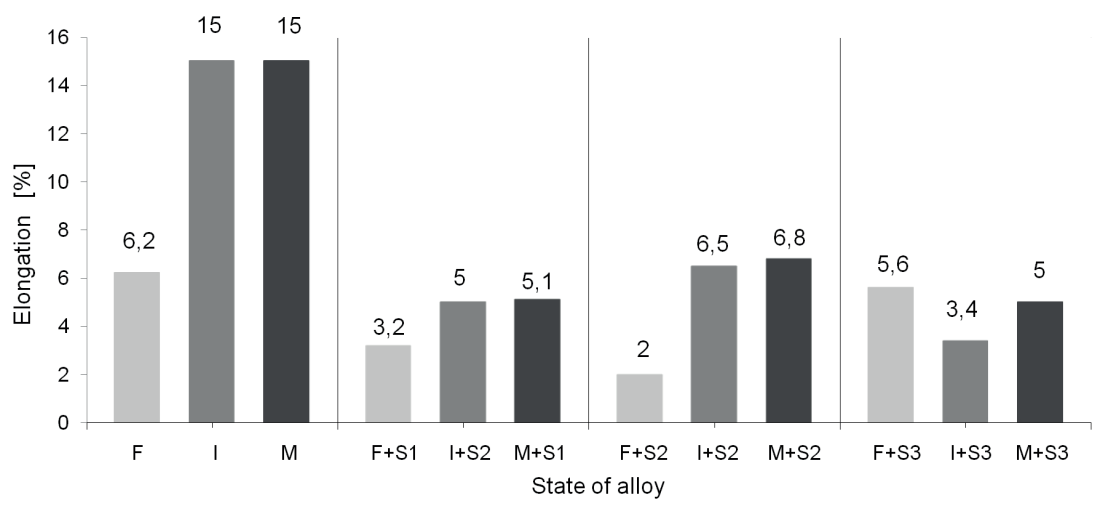

Fig. 12. Changes in elongation $E$ in elongation test at ambient temperature in as-cast state (F) depending on method of cooling during quenching (I or M) and variation of aging (S1, S2, or S3)

During the analysis of the achieved values (Fig. 12), the highest value of elongation can be observed at a level of approx. 15\% for micro-jet $(M)$ and immersion quenching $(I)$ without aging. Next, the highest value of elongation was achieved in the case of microjet quenching $(M)$ together with aging $S 2\left(175^{\circ} \mathrm{C}, 8 \mathrm{~h}\right)$.

\subsection{Correlations between particular mechanical properties for individual hypoeutectic silumins}

The static correlations were examined with regard to correlations between the mechanical properties in states $\mathrm{F}, \mathrm{T} 4$, and $\mathrm{T} 6$, with both immersion $(I)$ and micro-jet $(M)$ quenching.

Some of the relationships are shown in the present publication. From Figure 13 results a linear correlation (with a high coefficient of determination $R^{2}=0.75$ ) between hardness $H B$ and ultimate tensile strength UTS, described with equation $U T S=2.57 \mathrm{HB}-32.47$.

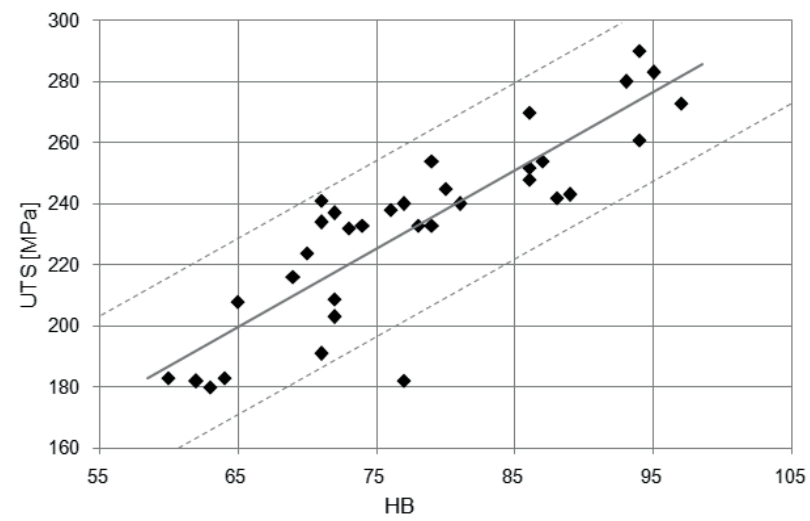

Fig. 13. Linear correlation between hardness of sample HB and ultimate tensile strength UTS 
A weaker correlation $\left(R^{2}=0.66\right)$ is observed for the linear correlation between hardness and yield stress in the tensile test (see Fig. 14).

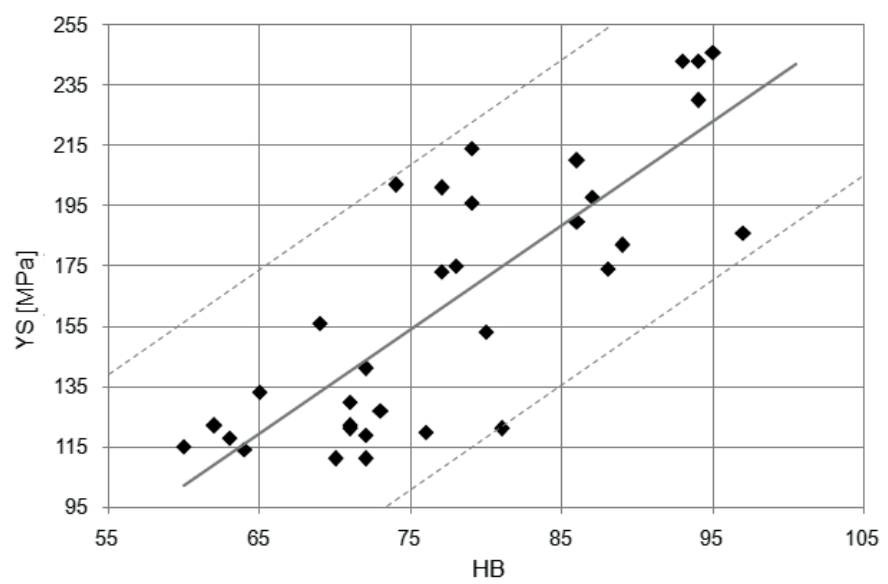

Fig. 14. Linear correlation between hardness of sample HB and yield stress YS

Between UTS and YS, there is also a certain linear correlation described with equation YS $=1.05$ UTS -81.02 (see Fig. 15)

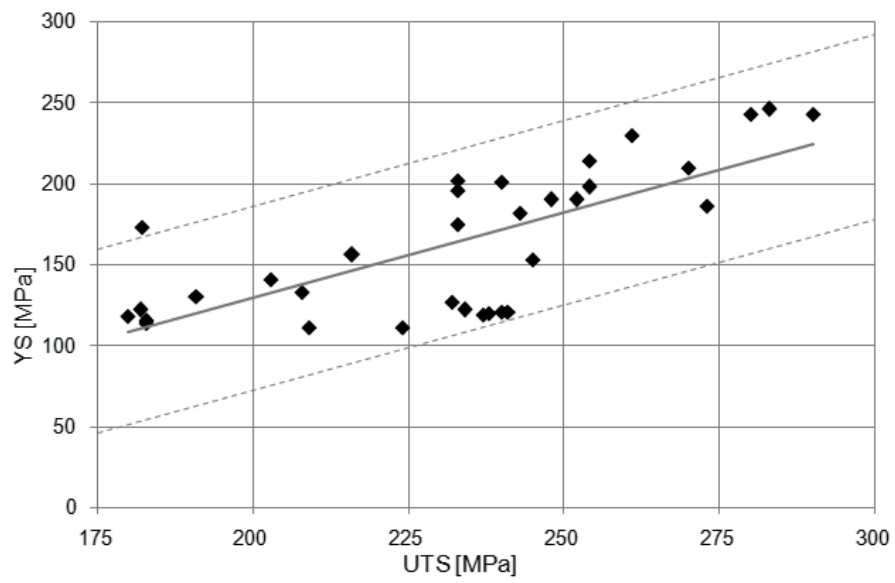

Fig. 15. Linear correlation between ultimate tensile strength UTS and yield stress YS

From the static correlation presented in Figure 16, the results are practically an ideal translation (with the coefficient of regression 0.99 and coefficient of determination $R^{2}=0.82$ ) between elongation $E$ and necking $N$. 


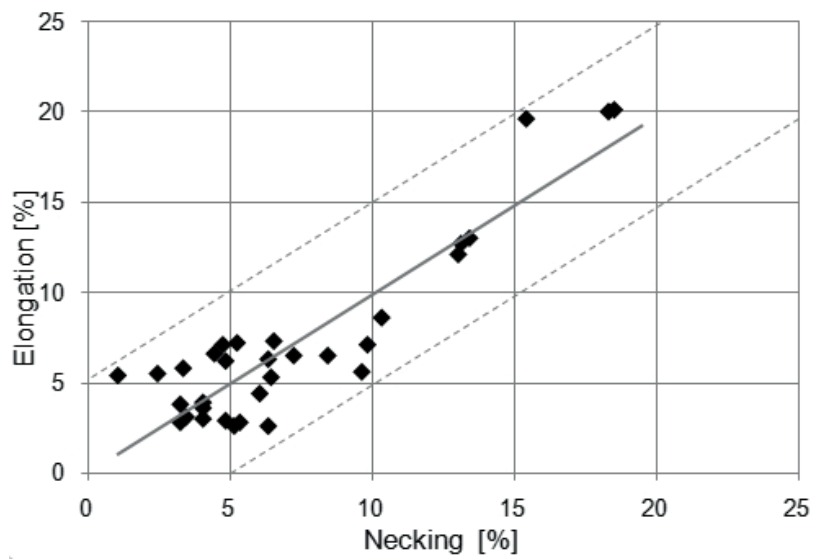

Fig. 16. Linear correlation between elongation $E$ and necking $N$

Between tensile strength parameters (UTS, YS, HB) and plasticity characteristics $(E, N)$, no linear correlations were observed with even a small coefficient of determination in the case of hypoeutectic silumin (type AISi7Mg0.3). In each analyzed set, this was close to zero (i.e., $R^{2} \approx 0.00$ ).

\section{Conclusions}

- Both the method of cooling during quenching $(/$ or $M)$ and the aging parameters $(S 1, S 2$, or S3) of alloy AISi7Mg0.3 influence the achieved levels of mechanical property parameters in the tensile test (UTS, YS, $E, N$, and $H B$ ) in relation to their values in as-cast state $\mathrm{F}$.

- The best results of UTS, YS, and $E$ were achieved for states $I+S 2$ and $M+S 2$. The use of micro-jet treatment positively influences these properties; however, the achieved effects are strongly related to the aging parameters (temperature and time) for variations $S 1, S 2$, and $S 3$.

- The figures presented in the publication present a high correlation between ultimate tensile strength (UTS) and yield stress (YS) and their correlation - also with a good linear approximation - in relation to hardness $(H B)$.

- The optimal selection of temperature and time of artificial aging of the examined aluminum alloy can lead to improved tensile strength properties (UTS, YS) and, at the same time, provide increased plasticity $(E, N)$.

- The achieved research results show that, depending on the method and parameters of heat treatment, it is possible to control (within a wide range, depending on the needs) the properties of cast alloy Al7Mg0.3. This explains its wide use in the production of cast construction elements. 
- The micro-jet cooling method during quenching is an effective way for partially improving the mechanical properties of Al-Si-Mg casting alloys and can be improved by applying higher pressure in the cooling media. It can be a good alternative for immersion cooling - especially with a local reinforcement of metal cast elements.

\section{Acknowledgements}

This article was based on tests results implemented within grant number 5940/B/ TO2/2010/38 commissioned by the Polish Ministry of Science and Higher Education.

\section{References}

[1] Novikov I.I.: Teoriya termicheskoy obrabotki metallov. Uchebnik. 3-ye izd. Metallurgiya, Moskva 1978 [Новиков И.И.: Теория термической обработки металлов. Учебник. 3-е изд. Металлургия, Москва 1978]

[2] Adel M., Fawzy S.: Performance of Aluminum-Silicon Cast Alloys. Effect of alloying and trace elements on the microstructure and mechanical properties if Al-Si Alloys. LAP LAMBERT Academic Publishing, Mannheim 2010

[3] PN-EN 1706:2011 - Aluminium i stopy aluminium. Odlewy. Skład chemiczny i własności mechaniczne. PKN, Warszawa 2011

[4] Hatch J.E. (ed.): Properties and Selection: Nonferrous and Special-purpose Materials. $10^{\text {th }}$ edition. ASM International, Ohio, USA 1975

[5] Hatch J.E. (ed.): Aluminium. Properties and Physical Metallurgy. $5^{\text {th }}$ edition. ASM International, Ohio, USA 1993

[6] Aristova N.A., Kolobnev I.F.: Termicheskaya obrabotka liteynykh alyuminiyevykh splavov. Metallurgiya, Moskva 1977 [Аристова Н.А., Колобнев И.Ф.: Термическая обработка литейных алюминиевых сплавов. Металлургия, Москва 1977]

[7] Czekaj E., Zych J., Kwak Z., Garbacz-Klempka A.: Quality Index of the AISi7Mg0.3 Aluminium Casting Alloy Depending on the Heat Treatment Parameters. Archives of Foundry Engineering, 16, 3 (2016), 25-28. DOI: 10.1515/afe-2016-0043

[8] Drouzy M.: Interpretation of Tensile Test Results Using Quality Index and Probable Elastic Limit-Application to Cast Al-Si-Mg Alloys. Revue de Métallurgie, 75, 1 (1978), 51-59

[9] Górny Z., Czekaj E. et al.:Wpływ chłodzenia mikrostrumieniowego podczas hartowania (przesycania) na strukturę i właściwości wybranych stopów. Badania eksperymentalne i symulacyjne. In: Sprawozdanie końcowe z projektu badawczego nr 5940/B/TO2/2010/38 realizowanego na zlecenie MNiSW. Foundry Researche Institute, Krakow 2013 (unpublished), 137-149, 164-171, 179-190

[10] Seifeddine S., Timelli G., Svensson I.L.: Influence of quench rate on the microstructure and mechanical properties of aluminium alloys A356 and A354. International Foundry Research/Giessereiforschung, 59, 1 (2007), 2-10

[11] Aluminum Alloys Cast at Coastal Foundry. http://www.coastalfoundry.com/alloys-cast/aluminum-alloys/AIAlloysChemicalsMechanicals.pdf (Coastal Foundry Company) [16.12.2016] 